\title{
A Comparative Study between Arbitration and Judicial Settlement as Means of Maritime Boundary Dispute Settlement
}

\author{
Md. Monjur Hasan"1,2, Md. Arifuzzaman ${ }^{3}$ \\ ${ }^{1}$ School of Law and Political Science, Ocean University of China, Qingdao, China \\ ${ }^{2}$ Gono Bishwabidyalay (University), Dhaka, Bangladesh \\ ${ }^{3}$ Institute of Environmental Science, University of Rajshahi, Rajshahi, Bangladesh \\ Email: monju.law10@gmail.com
}

How to cite this paper: Hasan, Md. M., \& Arifuzzaman, Md. (2018). A Comparative Study between Arbitration and Judicial Settlement as Means of Maritime Boundary Dispute Settlement. Beijing Law Review, 9, 75-86.

https://doi.org/10.4236/blr.2018.91006

Received: February 20, 2018

Accepted: March 12, 2018

Published: March 15, 2018

Copyright $\odot 2018$ by authors and Scientific Research Publishing Inc. This work is licensed under the Creative Commons Attribution International License (CC BY 4.0).

http://creativecommons.org/licenses/by/4.0/

\begin{abstract}
This paper makes an effort to draw a comparative study between judicial process and arbitration as the method of maritime boundary dispute settlement. Currently, maritime boundary dispute between states is a much talked issue all over the World. The United Nations Convention on the Law of the Sea refers four means of maritime dispute settlement ${ }^{1}$. Arbitration and Judicial processes are mainly two of them. According to the Convention every state has the right to choose one of the four means to settle their dispute ${ }^{2}$. Practices show that Arbitration and Judicial settlement are more popular than any other methods of maritime boundary dispute settlement. Most of the previous maritime boundary disputes have been settled either by judicial process or by Arbitration. The present paper attempts to compare between arbitration and Judicial process as the means of maritime boundary dispute. In addition, many of the concepts mentioned in this paper may use to understand about the peaceful settlement of maritime boundary dispute.
\end{abstract}

\section{Keywords}

Arbitration, Judicial Settlement, Maritime Dispute, Comparative Study, Convention

\section{Introduction}

Arbitration and Judicial process are two of the different methods of maritime boundary dispute according to United Nations Convention on the Law of the ${ }^{1}$ Article 287, United Nations Convention on the Law of the Sea, (Done at Motego Bay), 10 December 1982, in force 16 November 1994.

${ }^{2}$ Ibid. 
$\mathrm{Sea}^{3}$. Maritime boundary dispute settlement is an important issue of International Law because maritime boundary dispute is a common scenario all over the world. Although the UN Convention on the Law of Sea regulates all the segments of the sea-based issue the provisions regarding maritime boundary delimitation are not well defined and clear. The convention provides for the process of delimitation of different maritime zones between states shall be affected by agreement on the basis of international law in order to achieve an equitable solution. This provision directs the parties to the dispute to take initiative between them and make an agreement equitably first. It does not provide any definite delimitation procedure to be followed. If the party to the dispute fails to reach an agreement they can move towards the dispute settlement procedure under the law of the Sea convention stated in part XV of the convention.

There are two types of dispute settlement procedures in LOS convention. Section 1 of Part XV states the non-compulsory procedures which are the negotiation, the mediation and the conciliation and Section 2 of Part XV deals with the compulsory settlement procedure which includes ITLOS under Annex VI, the ICJ and Arbitral Tribunal created under Annex VII and the creation of a special Arbitral Tribunal formed as a panel of experts. The purpose of the present paper is to seek attention to the comparative discussion in brief between arbitration and judicial settlement of maritime boundary dispute.

\section{Maritime Boundary Dispute Settlement Procedure}

According to the article 287 of the United Nations Convention on the Law of the Sea, one state has the right to choose one or more of the following means to settle their disputes concerning the interpretation and application of this Convention:

1) The International Tribunal for the Law of the Sea (ITLOS),

2) The International Court of Justice (ICJ),

3) An Arbitral Tribunal constituted in accordance with Annex VII,

4) A Special Arbitral Tribunal constituted in accordance with Annex VIII ${ }^{4}$.

In settlement of maritime boundary disputes, the LOS Convention provides freedom to the States Parties concerned to settle their dispute through negotiation or other diplomatic measures between them. Parties can request to the court or Tribunal having jurisdiction over their disputed issues in case where there is no settlement between them. United Nations Convention on the Law of the Sea 1982 refers two types of maritime boundary dispute settlement process ${ }^{5}$. The system of dispute settlement is contained in two parts of United Nations Convention on the Law of the Sea. Part XI deals with the disputes relating to mining in the International Seabed Area and Part XV deals with all other disputes relating to the interpretation and application of UNCLOS. Section 1 of Part XV states ${ }^{3}$ Ibid.

${ }^{4}$ Article 287, United Nations Convention on the Law of the Sea, (Done at Motego bay), 10 December 1982, in force 16 November 1994.

${ }^{5}$ United Nations Convention on the Law of the Sea, (Done at Motego bay), 10 December 1982, in force 16 November 1994. 
the non-compulsory procedures which are the negotiation, the mediation and the conciliation and Section 2 of Part XV deals with the compulsory settlement procedure which includes ITLOS under Annex VI, the ICJ and Arbitral Tribunal created under Annex VII and the creation of a special Arbitral Tribunal formed as a panel of expert that discussed above.

\subsection{Arbitration}

Literally, arbitration means Settlement of a dispute between parties to a contract by a neutral third party without resorting to court action. It is usually voluntary but sometimes required by law. If both sides agree to be bound by the arbitrator's decision it becomes a binding arbitration.

The Arbitration is one of the four means for the settlement of maritime boundary disputes concerning the interpretation or application as stated in article 287 of the Convention ${ }^{6}$. The Arbitration under Annex VII is used for the settlement of disputes between parties that have not made a declaration of choosing procedure or for parties that have not accepted the same procedure for settlement of the dispute. So, it is a default procedure to settle the maritime dispute. Any party to the dispute may bring their case before Arbitration by written notification addressed to the other party with the statement of the claim and the ground on which it is based ${ }^{7}$. The Arbitration is composed of five members preferably chosen from the list of arbitrators which shall be drawn up and maintained by the Secretary General of the United Nations ${ }^{8}$. The party who institute the proceeding before the Arbitral tribunal shall appoints one member to be chosen preferably from the list of arbitrators, who may be its national. The other party, against which the proceeding is brought, also appoints one member among its nationals in the list within 30 days of getting of the notification addressed by the party that brings the case ${ }^{9}$. The rest of the three members shall be appointed jointly by the parties according to their agreement from the nationals of the third States unless the parties otherwise agree. One member out of these three will be appointed as the president of arbitral tribunal. If the party against which the case is made fail to do so within above-mentioned time or the parties are not able to reach an agreement on the appointment of arbitrator, the President of the International Tribunal for Law of the Sea (ITLOS), upon request and in consultation with the parties, shall make the necessary appointment. According to article 5 of Annex VII of the LOS Convention, the arbitral tribunal decides its own procedure, ensuring full opportunity to be heard and to present the case to each party ${ }^{10}$. The decisions of the arbitral tribunal depend on a majority vote of its members. In case of an equality of vote the President has a casting vote. The award mentions the subject matter of the dispute and states the reasons on which it is based, and the name of the members who have participated. The 
award shall be final without appeal, unless the parties to the dispute have agreed in advance to an appellate procedure and it will be binding upon the parties. Through arbitration, many of coastal states settled their longstanding maritime boundary delimitation disputes. In 2014, Bangladesh and India resolved their 40 years longstanding maritime boundary delimitation dispute which commenced in $1974^{11}$.

Some examples of the settlement of maritime boundary disputes can be mentioned here which have been settled through arbitration.

Australia and New Zealand v. Japan (Southern Bluefin Tuna Arbitration, 4 August, 2000); Ireland v. UK (Mox Plant Arbitration, 6 June, 2008); Malaysia v. Singapore (Land Reclamation Arbitration, 1 September, 2005); Barbados v. Trinidad and Tobago (Maritime Delimitation Arbitration, 11 April, 2006); Guyana v. Suriname (Maritime Delimitation Arbitration, 17 September, 2007); Bangladesh v. India (Bay of Bengal Maritime Boundary Arbitration, 7 July, 2014); Mauritius v. UK (Chagos Archipelago Arbitration, 18 march, 2015); Argentine v. Ghana (ARA Libertad Arbitration, 11 November, 2013); Philippines v. China (South China/West Philippines Sea Arbitration, 12 July, 2016); Denmark in respect of the Faroe Islands v. European Union (Atlanto-Scandian Herring Arbitration, 23 September, 2014) etc. ${ }^{12}$

\subsubsection{Advantages of Arbitration}

Arbitration is more flexible than the procedure followed by the ICJ or Judicial process. Statute and Rules of ICJ or ITLOS are defined in advance and are applied in the same manner to all cases brought before it. In the case of arbitration, particularly if a case is brought before the arbitral court on the basis of a special agreement, the parties have more freedom of movement and option.

All the proceedings of arbitration are generally confidential because it remains completely in the hands of the disputing parties. This confidentiality is useful in the case of maritime boundary disputes where, if the parties to such a dispute still have outstanding differences with other States over their maritime boundaries, they do not want that the arguments that they use in the dispute settlement proceedings to be made public because this may disadvantage their position in negotiating over their other unresolved maritime boundaries ${ }^{13}$. From appointment of the arbitrators to the decision about procedures and rules of arbitration are remained under the control of the disputing parties.

However, in the extreme condition of discord between the disputing parties as to the appointment of three other members, the President of the ITLOS is au-

\footnotetext{
${ }^{11}$ The Case of "The Bay of Bay of Bengal Maritime Boundary Arbitration between the People's Republic of Bangladesh and Republic of India" which was initiated by Bangladesh against India before Arbitral Tribunal on 8 October, 2009.

${ }^{12}$ Law of the Sea dispute settlement mechanism by Aceris Law, International Arbitration Attorney Network, 21/9/2015. Available at:

https://www.international-arbitration-attorney.com/law-of-the-sea-dispute-settlement-mechanism/ [Accessed on 15 February 2018].

${ }^{13}$ Freestone et al. (2006) The Law of the Sea: progress and prospects. Oxford University Press, P. 396.
} 
thorized to appoint these members ${ }^{14}$. These three members constitute the majority, thus the basic logic that the disputing parties have some control in the constitution of the arbitral tribunal stands little bit compromised. However, it also acts as impetus for the disputing parties to promptly agree on the remaining three members.

In arbitration there is no third party intervention in any dispute like the proceedings before any standing courts and tribunals. Without the wishes of disputing parties no third state can intervene in the proceeding to take any benefit. Thus, it provides flexibility and space to States to settle their dispute peacefully. It also gives chances that similar kinds of disputes can be settled using different principles with different States. The arbitration proceedings under Annex VII are time bound and the traditional excuses of delays are not available under this process.

\subsubsection{Disadvantages of Arbitration}

Extra expenditure for the appointments of arbitrator according to Annex VII of the convention is one of disadvantages of arbitration. Each disputing party appoints one member to the tribunal and the rest three are appointed jointly by the disputing parties ${ }^{15}$. So, States have to incur extra expenditures for their services. Arbitration tribunals involve high costs and high fees paid to arbitrators and court registrars, together with rental expenses of premises in which proceedings are carried on, secretarial and interpreting services, are well known for the adverse effect they have on public opinion whereas all costs of the ICJ are borne by the $\mathrm{UN}^{16}$.

Another possible disadvantage of arbitration is delay appointment of arbitrators and ill motive to get the appointment by the president of ITLOS in case the President belongs to the nationality of one of the disputing parties ${ }^{17}$. This arbitration procedure, being default in the situation of discord as to the choice of respective means under Article 287(1), can be invoked by any State party in diversified circumstances. In some circumstances, this option for the appointment by the President of ITLOS may be exploited with some ulterior motives. The core advantages and disadvantages of Arbitration are mentioned in Table 1.

\subsection{Judicial Settlement}

The Judicial process of maritime boundary dispute settlement consists of the following three institutions:

1) International Court of Justice (ICJ).

2) International Tribunal for the Law of the Sea (ITLOS).

3) Commission on the Limits of the Continental Shelf (CLCS).

International Court of Justice (ICJ) is an essential part of the United Nations

\footnotetext{
${ }^{14}$ Article 3 (e), Annex VII, United Nations Convention on the Law of the Sea 1982.

${ }^{15}$ Article 3 (b), (c) and (d), Annex VII, United Nations Convention on the Law of the Sea 1982.

${ }^{16}$ Kariotis (Ed.) (1997) Greece and the Law of the Sea. Hague: Kluwer Law International, p. 170.

${ }^{17}$ Ibid.
} 
Table 1. Advantages and disadvantages of arbitration.

\begin{tabular}{|c|c|}
\hline Advantages & Disadvantages \\
\hline $\begin{array}{l}\text { Parties create own process on the basis of agreement } \\
\text { between the parties. }\end{array}$ & $\begin{array}{l}\text { Success of arbitration largely depends on } \\
\text { arbitrators. }\end{array}$ \\
\hline $\begin{array}{l}\text { Arbitrator can be selected on basis of substantive } \\
\text { knowledge in respective issues. }\end{array}$ & $\begin{array}{l}\text { In Arbitration, time and cost is affected by } \\
\text { poor co-operation and poor process design. }\end{array}$ \\
\hline Arbitration is a confidential proceeding. & $\begin{array}{l}\text { In arbitral proceeding, right of appeal is } \\
\text { limited. }\end{array}$ \\
\hline $\begin{array}{l}\text { It compels proper behavior and may minimize bad } \\
\text { faith because it is a formal proceeding. }\end{array}$ & $\begin{array}{l}\text { Sometimes, confidentiality is not suitable for } \\
\text { some disputes. }\end{array}$ \\
\hline Rules of procedure can be customized to the process. & $\begin{array}{l}\text { Result of arbitration may be uncertain if it is } \\
\text { a binding arbitration. }\end{array}$ \\
\hline $\begin{array}{l}\text { The Award of Arbitration, whether it will be binding } \\
\text { or advisory it depends on the wishes of parties. }\end{array}$ & Extra expenses for the arbitrators. \\
\hline $\begin{array}{l}\text { Arbitration is less expensive because it consumes less } \\
\text { time. }\end{array}$ & Opportunity to make it binding or advisory. \\
\hline
\end{tabular}

and the largest judicial body of United Nations which is also called the World court. International Tribunal for the Law of the Sea (ITLOS) is the latest international judicial body which deals with the maritime dispute affairs under the Law of the Sea Convention. Commission on the Limits of the Continental Shelf is also a body that deals with the overlapping claim of extended continental shelf among states.

\subsubsection{The International Court of Justice}

The International Court of Justice is one of the integral parts of the United Nations based in The Hague, The Netherlands ${ }^{18}$. It is the major international judicial organ which has fifteen members or judges, elected separately by the U.N. General Assembly and the Security Council for a term of nine years ${ }^{19}$. Only states can bring controversial cases before it, either by special agreement between the parties to a dispute or by a unilateral application by either party ${ }^{20}$. Some particular international organizations, including the United Nations itself, can seek the "Advisory Opinion" from the Court ${ }^{21}$. The Court has actually settled a number of maritime boundary dispute, the first being the North Sea Continental Shelf Cases (1969) between former West Germany on one side and Denmark and the Netherlands on the other ${ }^{22}$. ICJ is entitled to exercise its jurisdiction over any dispute concerning the interpretation or application of LOS convention which is submitted to it under Article 287 and $288^{23}$. There are some ${ }^{18}$ See Statute of the International Court of Justice, June 26, 1945, art. 22, 59 Stat. 1057 [hereinafter ICJ Statute].

${ }^{19}$ See id. art. 13, 59 Stat. 1056.

${ }^{20}$ See id. art. 34, 59 Stat. 1059.

${ }^{21}$ See id. art. 65, 59 Stat. 1063.

${ }^{22}$ See North Sea Continental Shelf Cases (1969) (Federal Republic of Germany v. Denmark; Federal Republic of Germany v. Netherland.), 1969 I.C.J. 3 (Feb. 20).

${ }^{23}$ Article 287 and 288, United Nations Convention on the Law of the Sea (Done at Montego Bay), 10 December 1982, in force 16 November 1994. 
Judgments relating to maritime boundary dispute is mentioned here which have been declared by ICJ after the enforcement of LOS Convention in 1994.

Fisheries Jurisdiction (Spain v. Canada) 2001; Maritime Delimitation and Territorial Questions (Qatar v. Bahrain), 1998; Land and Maritime Boundary (Cameroon v. Nigeria: Equatorial Guinea intervening), 2002; Territorial and Maritime Dispute in the Caribbean Sea(Nicaragua v. Honduras), 2007; Territorial and Maritime Dispute (Nicaragua v. Colombia), 2012; Maritime Delimitation in the Black Sea (Romania v. Ukraine), 2009; Maritime Dispute (Peru v. Chile), 2014; Whaling in the Antarctic (Australia v. Japan: New Zealand intervening), $2014^{24}$.

Presently, the following maritime boundary delimitation cases are in the pending list before the ICJ.

1) Question of the delimitation of the Continental shelf between Nicaragua and Colombia beyond 200 nautical miles from the Nicaraguan Coast (Nicaragua v. Colombia) (Case no. 5, Pending case list) ${ }^{25}$.

2) Maritime Delimitation in the Caribbean Sea and the Pacific Ocean (Costarica v. Nicaragua) (Case no. 7, Pending case list) ${ }^{26}$.

3) Maritime Delimitation in the Indian Ocean (Somalia v. Kenya) (Case no. 8, Pending case list) ${ }^{27}$.

\subsubsection{The International Tribunal for the Law of the Sea}

Particularly for the settlement of maritime disputes, the International Tribunal for the Law of the Sea is one of the notable creations established in October 1996 with its seat in Hamburg, Germany ${ }^{28}$. At the Conference of the States Parties to the Convention held at the United Nations headquarters in New York in August $1996^{29}$, the twenty-one judges of the Tribunal were each elected for a nine-year tenure (staggered to three, six and nine years for each group of seven in the first election $)^{30}$. The jurisdiction of this Tribunal is not exclusive to the extent that the parties to a dispute may choose it as one of the four judicial means open to them. The Tribunal decided its first case in December $1997^{31}$ and the second in March $1998^{32}$, with the third in June 1999. All three cases involve a St. Vincent and the Grenadines oil tanker, the Saiga, which was seized by Guinea in the offshore waters of Guinea in October 1997, allegedly for smuggling ${ }^{33}$.

\footnotetext{
${ }^{24}$ Supra note 12 .

${ }^{25}$ Pending Case List, ICJ. Available at: http://www.icj-cij.org/en/pending-cases [Accessed on 16 February 2018].

${ }^{26}$ Ibid.

${ }^{27}$ Ibid.

${ }^{28}$ Article 1 and 2, Annex VI, United Nations Convention on the Law of the Sea 1982.

${ }^{29}$ See Oceans and the Law of the Sea, Settlement of Disputes, Available at: http://www.in.org./depts/los/los_disp.htm. (Accessed on 17 February, 2018).

${ }^{30}$ Article 2, 1and 5, 1, Annex VI, United Nations Convention on the Law of the Sea 1982.

${ }^{31}$ See St. Vincent and the Grenadines v. Guinea (The M/V “Saiga”), 37 I.L.M. 360 (Int'1 Trib. for Law of Sea, December. 4, 1997) [hereinafter St. Vincent I].

${ }^{32}$ See St. Vincent and the Grenadines v. Guinea (The M/V “Saiga”), 37 I.L.M. 1202 (Int'l Trib. for Law of Sea, March 11, 1998) [hereinafter St. Vincent II].

${ }^{33}$ See St. Vincent I, 37 I.L.M. at 367.
} 
There are 25 cases registered before the ITLOS till now among them most of are "prompt release" related case. Only 2 cases were about maritime boundary delimitation; one is "Dispute concerning delimitation of the maritime boundary between Bangladesh and Myanmar in the Bay of Bengal" (Case no. 16, ITLOS) ${ }^{34}$ case which began in December 14, 2009, and ended in March 14, 2012 another one is "Dispute Concerning Delimitation of the Maritime Boundary between Ghana and Côte d'Ivoire in the Atlantic Ocean" (Case no. 23, ITLOS) ${ }^{35}$ which began in December 3, 2014, and ended in September 23, 2017.

Unlike the Court, the Tribunal can give Advisory Opinions only with respect to specific seabed disputes referred to it by the Jamaican-based International Seabed Authority, which was also established by the Convention ${ }^{36}$.

\subsubsection{Commission on the Limits of the Continental Shelf (CLCS)}

Commission on the limits of the continental shelf has been established under Annex 2 of the LOS Convention. The Commission consists of 21 members, experts in the field of geology and physics ${ }^{37}$. Generally, every state claims Continental shelf up to $200 \mathrm{~nm}$ but sometimes they claim their continental shelf beyond $200 \mathrm{~nm}$ which creates boundary dispute between coastal states. In this regard, the LOS convention has created the commission of continental shelf to hear the arguments of the parties to the dispute in favor of their claim. The decision or recommendation of this commission is binding for all the parties to the Law of the Sea convention.

Seventy-seven States have already filed their submissions to seek recommendations before the Commission and twenty nine Recommendations have been issued so $\mathrm{far}^{38}$.

\subsubsection{Advantages of Judicial Settlement}

Throughout special agreement under Article 36(1) of the Statute to submit the dispute to the ICJ has the advantage of the dispute being concisely defined in the special agreement $t^{39}$. Basically, contesting parties may agree through the special agreement and in advance on the exact extent and content of their dispute, avoiding thereby subsequent submission of preliminary exceptions by the defendant, as can happen and has often taken place in cases of unilateral applications. During bilateral talks for special agreement, both litigants may agree to refer only part of their dispute to the Court, leaving final settlement to their own

\footnotetext{
${ }^{34}$ The case of "Dispute Concerning Delimitation of the Maritime Boundary between Bangladesh and Myanmar in the Bay of Bengal"(Case no. 16, ITLOS) which was instituted by Bangladesh against Myanmar on 13 December, 2009 before International Tribunal for the Law of the Sea.

${ }^{35}$ Dispute Concerning Delimitation of the Maritime Boundary between Ghana and Côte d'Ivoire in the Atlantic Ocean" (Case no. 23, ITLOS) which began in December 3, 2014, and ended in September 23, 2017.

${ }^{36}$ Article 159 (10), United Nations Convention on the Law of the Sea 1982.

${ }^{37}$ Article 2, Annex II, United Nations Convention on the Law of the Sea 1982.

${ }^{38}$ Division for Ocean affairs and the Law of the Sea, United Nations. Available at:

http://www.un.org/depts/los/clcs_new/commission_submissions.htm [Accessed on 14 February, 2018].

${ }^{39}$ Article 36 (1), Statute of International Court of Justice 1945.
} 
discretion. In judicial settlement there is less opportunity for abusing of the process. In this process the parties to the dispute are compelled to attend the proceeding. Because of institutionalized process it allows safeguards for the parties. The decision declared by the court or tribunal is binding for the disputed parties. Through this process legal precedent may be established for the upcoming or future maritime dispute settlement.

In Judicial settlement, no extra expenditure for the appointments of judges of court or tribunal is necessary like arbitration. Judicial process does not involve high expenses and high fees paid to the Judges and court registrars, together with rental expenses of premises in which proceedings are carried on; all costs of the ICJ are borne by the $\mathrm{UN}^{40}$. In this process there is no scope of making delay regarding appointment of Judges or member of court or tribunal like arbitration because the court or tribunal is established institution.

\subsubsection{Disadvantages of Judicial Settlement}

In some extent, the procedure followed by the judicial settlement is more rigid than arbitration. Statute and Rules of ICJ or ITLOS are defined in advance and are applied in the same manner to all cases brought before it but in arbitration the parties to the dispute get freedom of choice of procedure based on their agreement. Judicial settlement consumes more times than arbitration because the rules of judicial process is defined and strictly followed. Its involvement with other categories of disputes generally may delay the legal process relating to the law of the sea disputes. It is not always possible to get prompt and effective remedy from the ICJ.

In case of judicial settlement, the parties to the dispute are not in control of the process or decision of court or tribunal like arbitration so that the outcome is in uncertainty. It is a public process; that is why, everything is expressly declared. So, it is not confidential like arbitration. The judicial settlement is regulated by the statutes. So, sometimes it has a limited remedy which depends on evidentiary documents. In Judicial process, the parties to the dispute are not authorized to keep any role for the appointment of members or judges of the court or tribunal like arbitration. So, the disputing parties in most cases are unable to compromise their dispute promptly. Judicial settlement process is an expensive undertaking of maritime dispute settlement than that of arbitration. As a result, most of the developing countries have not preferred judicial process as the first means of settlement rather they have treated it as secondary priority. The key advantages and disadvantages of Judicial Settlement are stated in Table 2.

\section{Similarities and Differences between the Two Processes}

Arbitration and Judicial process are the most accepted means for maritime boundary disputes settlement till now. Most of the disputes have been settled through these processes. With some similarities, a number of differences are

${ }^{40}$ Kariotis (Ed.) (1997) Greece and the Law of the Sea. Hague: Kluwer Law International, p. 170. 
obvious between the two existences regarding their compositions and proceedings. Both of the procedures are contained in section 2 of part XV of the United Nations Convention on the law of the Sea as compulsory means of settlement ${ }^{41}$. The major similarities and differences between these two processes are shown in Table 3.

\section{Conclusion}

Arbitration and Judicial process are two different means of maritime boundary

Table 2. Advantages and disadvantages of judicial settlement.

\begin{tabular}{ll}
\multicolumn{1}{c}{ Advantages } & \multicolumn{1}{c}{ Disadvantages } \\
\hline $\begin{array}{l}\text { In this process, there is less opportunity for abuse of } \\
\text { process because it is a formal procedure. }\end{array}$ & It is a time consuming process. \\
$\begin{array}{l}\text { Because of strict rules parties compelled to attend in the } \\
\text { proceeding. }\end{array}$ & $\begin{array}{l}\text { In Judicial process parties not in } \\
\text { control of process or decision. }\end{array}$ \\
$\begin{array}{l}\text { It allows safeguards because of Institutionalized process. } \\
\text { Judicial decision is binding for the parties. }\end{array}$ & $\begin{array}{l}\text { It is public process not confidential. } \\
\text { Legal precedent may be established through judicial } \\
\text { settlement. }\end{array}$ \\
$\begin{array}{l}\text { No extra expenditure for the Judges or Members like } \\
\text { arbitrators. }\end{array}$ & $\begin{array}{l}\text { Available remedies limited because of } \\
\text { well established rules of the courts. }\end{array}$ \\
\hline
\end{tabular}

Table 3. Similarities and differences between arbitration and judicial settlement.

\begin{tabular}{|c|c|}
\hline Similarities & Differences \\
\hline Compulsory settlement process. & Number of Judges and Arbitrators are different. \\
\hline $\begin{array}{l}\text { Contained in same section of same part } \\
\text { of LOS Convention. }\end{array}$ & $\begin{array}{l}\text { Members of the Arbitral tribunal are appointed by } \\
\text { the parties but judges have already been appointed in } \\
\text { Courts or Tribunals. }\end{array}$ \\
\hline $\begin{array}{l}\text { Acceptance of jurisdiction in both of the } \\
\text { processes depends on the wishes of the } \\
\text { parties. }\end{array}$ & $\begin{array}{l}\text { The parties have to spend extra expenditure for } \\
\text { arbitrators but in judicial process United Nations } \\
\text { bears all the expenditures. }\end{array}$ \\
\hline $\begin{array}{l}\text { Third party is always involved in both of } \\
\text { the processes. }\end{array}$ & $\begin{array}{l}\text { The decision of Arbitration may be advisory or } \\
\text { binding but the decisions of the Court are always } \\
\text { binding. }\end{array}$ \\
\hline $\begin{array}{l}\text { More successful than other mechanism } \\
\text { of maritime boundary dispute } \\
\text { settlement. }\end{array}$ & $\begin{array}{l}\text { The proceeding of Arbitration is run by the } \\
\text { agreement between the parties. On the other hand, } \\
\text { proceeding of the court is controlled by the well } \\
\text { established rules of the court or tribunal. }\end{array}$ \\
\hline $\begin{array}{l}\text { Arbitrators and Judges usually use the } \\
\text { principles of international law as the } \\
\text { basis for their decisions. }\end{array}$ & $\begin{array}{l}\text { Judicial settlement consumes more times than } \\
\text { Arbitration. }\end{array}$ \\
\hline $\begin{array}{l}\text { The legality of Arbitration and Judicial } \\
\text { Settlement generates international } \\
\text { reputation costs. }\end{array}$ & $\begin{array}{l}\text { Arbitration is a confidential and more flexible } \\
\text { process but judicial settlement is a public and rigid } \\
\text { process. }\end{array}$ \\
\hline
\end{tabular}

\footnotetext{
${ }^{41}$ Supra note 5 .
} 
dispute settlement categorized as compulsory method ${ }^{42}$. When the parties to the dispute fail to resolve the dispute through different non-compulsory procedures like negotiation, mediation and conciliation but need to solve it to explore marine resources they turn to this default method. The International Court of Justice (ICJ), The International Tribunal for the Law of the Sea (ITLOS) and Commission on the Limits of the Continental Shelf (CLCS) are the major bodies of judicial settlement regarding maritime boundary dispute. Without any agreement between disputing parties, no authority is entitled to start any proceeding against any of the disputed party. This is the major limitation or weakness of international law. Judicial settlement and Arbitration are not exception of it. With a number of differences, both of the processes have some advantages and disadvantages as well as some limitations also with regard to dispute settlement. Currently, Arbitration and Judicial Settlement process are the most trusted methods of maritime boundary dispute. Many of the longstanding maritime disputes between different coastal states have been settled following these processes. The present paper tried to address the comparative study in brief between the said processes. So, further research may be necessary to make details comparison between them. In addition, the best process for peaceful settlement of maritime boundary dispute may be detected through more and more researches.

\section{References}

(1969). North Sea Continental Shelf Case (Federal Republic of Germany v. Denmark; Federal Republic of Germany v. Netherlands). ICJ Reports 4 at 42.

(2009). The Bay of Bay of Bengal Maritime Boundary Arbitration between the People's Republic of Bangladesh and Republic of India, Arbitral Tribunal.

Dispute Concerning Delimitation of the Maritime Boundary between Bangladesh and Myanmar in the Bay of Bengal. ITLOS, 2009.

Dispute Concerning Delimitation of the Maritime Boundary between Ghana and Côte d'Ivoire in the Atlantic Ocean. ITLOS, 2014.

Division for Ocean Affairs and the Law of the Sea, United Nations. http://www.un.org/depts/los/clcs_new/commission_submissions.htm

Freestone, D. et al. (2006). The Law of the Sea: Progress and Prospects. Oxford: Oxford University Press, 396. https://doi.org/10.1093/acprof:oso/9780199299614.001.0001

Kariotis, T. C. (Ed.) (1997). Greece and the Law of the Sea. Hague: Kluwer Law International, 170 .

Law of the Sea Dispute Settlement Mechanism by Aceris Law, International Arbitration Attorney Network. 21/9/2015.

https://www.international-arbitration-attorney.com/law-of-the-sea-dispute-settlementmechanism/

Oceans and the Law of the Sea, Settlement of Disputes. http://www.in.org./depts/los/los_disp.htm

Pending Case List, ICJ. http://www.icj-cij.org/en/pending-cases

Statute of the International Court of Justice. (Done at San Francisco), 26 June 1945, in

${ }^{42}$ Section 2, Part XV, United Nations Convention on the Law of the Sea, 1982. 
Force 24 October 1945.

United Nations Convention on the Law of the Sea, (Done at Motego Bay). 10 December 1982, in Force 16 November 1994. 